\title{
PRODUÇÃO DE UMA TOPOGRAFIA SOCIAL URBANA
}

\author{
the production of a urban social topography
}

Ederson Nascimento *

\begin{abstract}
Resumo
O presente artigo apresenta reflexões sobre o papel do sítio urbano no processo de produção do espaço urbano. As características topográficas são abordadas na condição de importante elemento estruturador do espaço ao influenciarem as possibilidades de uso da terra para fins urbanos, sendo que a apropriação e uso desigual dos compartimentos do relevo contribuem para uma maior diferenciação socioespacial. A consequência é a consolidação de uma organização espacial que configura o que se está chamando de topografia social, espacialidades urbanas nas quais há uma correspondência muito próxima entre os desníveis do terreno e as disparidades sociais. Como exemplo, é apresentada uma análise da cidade de Ponta Grossa, no Paraná, onde tais influências da topografia sobre a evolução socioespacial são marcantes.
\end{abstract}

Palavras-chave: Expansão urbana, Ocupação e uso da terra, Desigualdades socioespaciais, Topografia social.

\section{Abstract}

This paper presents reflections about the role of urban site in the production process of urban space. Topographic characteristics are discussed as the main structural element of the space to influence the possibilities of urban land use, and the appropriation and unequal use of compartments relief contribute to a higher socio-spatial differentiation. The result is the consolidation of a spatial organization that constitute what is called the social topography, urban spatialities in which there is a closely match between the slope of relief and social disparities. As an example, an analysis is presented considering Ponta Grossa city, Parana State, Brazil, where such influences of the topography on spatial and social evolution are striking.

Key words: Urban expansion, Occupation and land use, Spatial and social inequalities, Social topography.

\section{Résumé}

Cet article présente des réflexions sur le rôle du site urbain dans la production de l'espace urbain. Les caractéristiques topographiques sont discutées comme un important element pour la structuration de l'espace, une fois qu'il agit sur les possibilités d'utilisation des terres à des fins urbaines, étant que l'appropriation et l'usage inégaux des compartiments du relief contribuent à une plus grande différenciation sociospatiale. Le résultat est la consolidation d'une organisation spatiale qui contemple ce que l'on appelle la topographie sociale, des spatialités urbaines dans lesquelles il y a une correspondance très proche entre les dénivellations du terrain et les disparités sociales. À titre d'exemple, l'on présente une analyse sur la ville de Ponta Grossa, État de Paraná, au Brésil, où telles influences sur l'évolution sociospatiale sont remarquables.

Mots-clés: Expansion urbaine, Occupation et utilisation de la terre, Inégalités sociospatiales, Topographie sociale.

(*) Prof. Msc da Universidade Federal da Fronteira Sul, Campus Chapecó - Avenida Fernando Machado, 108E, CEP: 89802102 - Chapeco (SC), Brasil - Tel: (+55 49) 20493127 - ederson.nascimento@uffs.edu.br 


\section{INTRODUÇÃO}

De um modo geral, a configuração do relevo exerce influências sobre determinadas características socioespaciais de uma cidade no decorrer de sua evolução histórica. Aspectos como o traçado e a forma urbanos dependem, em certa medida, das condições topográficas, assim como os modos de uso e ocupação da terra e a distribuição dos segmentos sociais no espaço. Em muitas ocasiões, as características topográficas impõem restrições a determinados tipos de ocupação das terras, seja devido a restrições impostas pela legislação ou pela própria impossibilidade de uso, sendo que estas acabam sendo apropriadas e aproveitadas distintamente para fins urbanos, seja para o desenvolvimento de atividades econômicas ou para a produção da moradia.

Sob este ponto de vista, a topografia deve ser vista não apenas como o substrato no qual a sociedade produz a cidade ao edificar suas obras e desenvolver suas atividades, mas também como uma importante dimensão de análise da própria produção do espaço na cidade, uma vez que suas características, ao favorecerem ou dificultarem a implementação de determinados usos da terra, tendem a tornar determinados locais mais ou menos atrativos à ocupação, o que acaba influenciando no preço da terra urbana. Portanto, mais do que natural, a topografia pode se tornar social ao ser apropriada e utilizada de modo desigual pela sociedade urbana.

Longe de pretender a defesa de qualquer "determinismo ambiental", subestimando as forças sociais ou superdimensionando o "peso" do relevo na configuração espacial, nossa principal intenção neste ensaio é enfatizar a relação sociedade-natureza, de longa tradição no pensamento geográfico, no processo de produção do espaço urbano através da influência direta da topografia - por vezes relegada a segundo plano em estudos sobre a evolução socioespacial nas cidades - sobre as ações dos agentes de tal processo.

A perspectiva da topografia social é desenvolvida a partir de uma análise da cidade de Ponta Grossa, no Paraná. Com uma população de aproximadamente 305 mil habitantes segundo o censo demográfico de 2010, Ponta Grossa é uma das principais cidades do interior paranaense, cuja evolução socioespacial foi fortemente influenciada pelas características de sua topografia, mais precisamente pela influência que esta exerceu no crescimento horizontal da cidade e pela apropriação e uso socialmente desigual de compartimentos do relevo (divisores topográficos, encostas e fundos de vale).

O texto está organizado em duas partes. Na primeira são apresentadas reflexões teórico-conceituais acerca dos principais elementos que levam à conformação do que se está chamando de topografia social, apresentando as principais condicionantes dos atributos físicos do terreno na produção de localizações e para a apropriação e uso socialmente desigual do espaço urbano. Por sua vez, na seção final apresenta-se o estudo de caso sobre Ponta Grossa, realizando uma descrição do encaminhamento metodológico adotado na pesquisa e analisando as principais características da topografia social constatadas na referida cidade paranaense.

\section{REFLEXÕES SOBRE A CONFIGURAÇÃO TOPOGRÁFICA E A PRODUÇÃO DO ESPAÇO URBANO}

A configuração espacial que assume a cidade exprime as características do desenvolvimento das atividades produtivas, bem como as contradições inerentes à formação econômico-social, pois esta ganha concretude no espaço. A cidade pode ser concebida, num primeiro momento de sua apreensão, como importante meio de produção. Esta, na acepção de Lefebvre (2001, p. 49), "[...] concentra não só a população, mas os instrumentos de produção, o capital, as necessidades, os prazeres", em suma, "[...] tudo o que faz com que uma sociedade seja uma sociedade". A aglomeração de pessoas na forma de força de trabalho e de consumidores, aliada à concentração dos meios de produção, permite que as forças produtivas alcancem um elevado grau de desenvolvimento, acelerando assim a realização da mais-valia e a reprodução do capital. 
Contudo, como bem afirma Souza, “[...] uma cidade não é apenas um local em que se produzem bens e onde esses bens são comercializados e consumidos, e onde pessoas trabalham". Mais do que isto, é também

[...] um local onde pessoas se organizam e interagem com base em interesses e valores os mais diversos, formando grupos de afinidade e de interesse, menos ou mais bem definidos territorialmente com base na identificação entre certos recursos cobiçados e o espaço, ou na base de identidades territoriais que os indivíduos buscam manter e preservar. (SOUZA, 2003, p. 28)

Portanto pode-se caracterizar a cidade, em síntese, como um local onde o plano da produção capitalista de mercadorias se relaciona com o plano do lugar, da vivência humana em sua dimensão plena, e seu espaço é reflexo e condicionante das diversas estratégias engendradas pelos diferentes agentes sociais na criação e apropriação da riqueza (produção e comercialização de mercadorias), da reprodução da força de trabalho e do desenrolar da vida cotidiana como um todo (educação, compras, atividades culturais, ócio, lazer etc.).

O modo de apropriação do espaço urbano pelos distintos segmentos sociais é expresso através do uso da terra. No entanto, a apropriação de uma porção de terras está vinculada ao processo de troca que se realiza no mercado, uma vez que o produto capitalista só pode ser concretizado a partir do processo de apropriação, no caso específico, via propriedade privada (CARLOS, 1994).

A importância assumida pela terra urbana enquanto condição essencial para a realização de qualquer atividade confere a ela o caráter de mercadoria, assumindo assim um determinado preço a ser pago pelos indivíduos desprovidos do direito de propriedade privada. Enquanto simples matéria, elemento da natureza, a terra não possui valor, pois não pode ser reproduzida pelo trabalho humano. Todavia, enquanto componente do espaço geográfico, a terra transcende a condição de mera superfície, sítio das edificações, e agrega atributos específicos que viabilizarão, em maior ou menor grau, as necessidades de produção e consumo no espaço urbano (RIBEIRO, 1997). Em função disso, pode-se dizer que a terra urbana assume a condição de mercadoria, apresentando um valor de uso, dado pela sua condição de elemento vital, não reprodutível e indispensável à atividade humana, além de um valor de troca, pois diante da demanda e da possibilidade iminente de acumulação de riqueza que a mesma representa a quem tenha sua posse, assume um preço (HARVEY, 1980).

A determinação do preço de uma porção do solo urbano depende de dois conjuntos de fatores: os atributos físicos do terreno e, os que exercem mais peso em processo de valorização, a sua localização no contexto geral da cidade. Estes dois conjuntos, no entanto, não se excluem, mantendo certa relação entre si.

Na acepção de Villaça (1998), a localização de uma área influenciará em seu preço imobiliário na medida em que esta condiciona a acessibilidade aos demais pontos do espaço urbano, seja para a realização da produção enquanto força de trabalho, seja para o próprio consumo do espaço. Assim, são variáveis que exercem grande peso no preço da terra urbana o acesso facilitado aos locais de trabalho, a disponibilidade de serviços e equipamentos urbanos (escolas, centros de saúde, locais de lazer, shoppings etc.), a infraestrutura disponível (saneamento básico, pavimentação e condições gerais do sistema viário, disponibilidade de transporte). A estes somam-se ainda o potencial de construtibilidade concedido por legislações urbanas, bem como fatores ligados à "imagem" do local (padrão das edificações no entorno e a presença ou não de aspectos negativos como barulho, criminalidade, prostituição, entre outros).

Todos estes aspectos que conferem atributos locacionais específicos à terra urbana têm em comum o fato de serem produto do trabalho humano, desempenhado por diversos agentes sociais na produção da cidade.

A localização se apresenta, assim, como um valor de uso da terra - dos lotes, das ruas, das praças, das praias - o qual, no mercado, se traduz em preço da terra. Tal como qualquer valor, o da localização 
também é dado pelo tempo de trabalho socialmente necessário para produzi-la, ou seja, para produzir a cidade inteira da qual a localização é parte (VILLAÇA, 1998, p. 334).

Por sua vez, o conjunto de localizações que estruturam o espaço urbano assenta-se sobre uma base física, "[...] a partir de um relevo, que é apropriado de forma desigual e combinada" (NUNES; SANT'ANNA NETO, 2002, p. 61). É sobre o relevo, isto é, a partir dos diferentes compartimentos geomorfológicos, que os agentes sociais produzem o espaço urbano modificando a natureza e (re) construindo suas realizações materiais (arruamentos, edificações, canalizações de cursos d'água etc.), socializando, portanto, as formas topográficas, transformando-as em "formas-conteúdo" (SANTOS, 1996).

A participação dos atributos físicos do terreno no preço da terra dá-se à medida que estes influem na qualidade da localização da mesma. Em primeiro lugar, as características topográficas, especialmente o grau de inclinação das vertentes e o nível de umidade do terreno, podem impor restrições à expansão do tecido urbano ao dificultar e/ou encarecer os processos de loteamento e de construção de edificações.

Ademais, convém lembrar que existem limitações jurídicas para o parcelamento e a ocupação de terrenos com determinadas características naturais. No caso brasileiro, em nível federal, a lei $\mathrm{n}^{\circ} 6.766 / 1979$, que dispõe sobre o parcelamento do solo urbano, estabelece no seu artigo $3^{\circ}$ que:

[...] Não será permitido o parcelamento do solo:

I - em terrenos alagadiços e sujeitos a inundações, antes de tomadas as providências para assegurar o escoamento das águas; [...]

III - em terreno com declividade igual ou superior a 30\% (trinta por cento), salvo se atendidas exigências específicas das autoridades competentes;

IV - em terrenos onde as condições geológicas não aconselham a edificação [...] (BRASIL, 1979).

Há também restrições em relação à ocupação de fundos de vales e margens de corpos e cursos d'água. A esse respeito, a referida lei estabelece a reserva de uma faixa não edificável de 15 (quinze) metros ao longo de águas correntes. Já a lei federal $n^{\circ} 7.803 / 1989$, que entre outras providências reformula algumas normatizações do "Código Florestal" (lei federal n 4.774/1965), estabelece uma área de reserva ainda maior para os cursos d'água, sendo mais comuns para áreas urbanas os valores de trinta metros para cursos d'água de até dez metros de largura, de cinquenta metros para cursos d'água com largura entre dez e cinquenta metros, e de cem metros para cursos d'água com larguras entre cinquenta e duzentos metros. Inclui ainda como terras não edificáveis o entorno de corpos d'água e áreas situadas a até cinquenta metros de nascentes.

Além das leis anteriormente citadas, há ainda outras normatizações legais estabelecidas em âmbitos estadual e municipal, que aprimoram e/ou restringem ainda mais as determinações federais, ou que instituem outras áreas de preservação ambiental. Seja como for, estes entraves legais tendem a diminuir o interesse do mercado imobiliário por glebas que apresentem terras com as características naturais tidas como non aedificandi, diante da limitada possibilidade de parcelamento e ocupação da gleba, do baixo percentual de aproveitamento da gleba ou, ainda, devido aos altos custos das obras necessárias para adequar o loteamento às exigências do órgão ambiental ou poder público municipal.

Todavia, a legislação é antes de tudo uma construção social, de modo que sua formulação e aplicação estão inseridos no contexto da sociedade e se explicitam por meio de contradições. Há diversas leis que não são cumpridas, ou que na prática são válidas apenas para alguns (SCHWARZ, 2005). Daí não serem raras as ocasiões em que o poder público, influenciado por pressões de proprietários fundiários e promotores imobiliários, faz "vistas grossas" à legislação, permitindo a expansão do tecido urbano para áreas ambientalmente impróprias à ocupação urbana.

Por outro lado, como aponta Corrêa (1986), há ocasiões em que os atributos naturais de uma área podem ser apropriados na forma de amenidades físicas, de modo a agregar maior valor co- 
mercial à terra. São exemplos disso os casos de áreas com beleza natural reconhecida (proximidade de lagos, encostas com florestas naturais, praias e dunas, entre outras) onde o aspecto cênico da paisagem é utilizado como indexador de valor à área. Nestes locais, ainda que existam restrições ambientais à ocupação urbana, o grande capital financeiro-fundiário-imobiliário investe na criação de áreas residenciais aprazíveis voltadas às camadas de renda mais elevada, dotando a área das obras de infraestrutura necessárias e intervindo para a legalização do empreendimento. Convém acrescentar que algumas amenidades ambientais também podem ser criadas a partir da ação do poder público municipal, por exemplo, na criação de parques em áreas de preservação permanente, como os fundos de vale.

Muitas das áreas de amenidades correspondem a terrenos ambientalmente frágeis, onde a ocupação urbana deveria ser necessariamente evitada por razões de proteção de mananciais e de espécies faunísticas, ou ainda em razão dos riscos à integridade física de quem as habita. No entanto, esta dinâmica de ocupação de áreas "de risco" se torna muito mais dramática quando associada à questão da dificuldade de acesso à moradia, enfrentada por uma ampla parcela da população pobre nas cidades brasileiras.

Os interesses do capital fundiário e imobiliário, pautados no valor de troca da terra em detrimento de seu valor de uso, são os que têm prevalecido na condução do processo de expansão horizontal e organização do espaço na ampla maioria das áreas urbanas no país. Aliada à fraca atuação do Estado na produção de habitações de interesse social, tal situação tem levado ao aumento da ocupação de áreas não edificáveis, seja na forma de loteamentos clandestinos, implantados sem a aprovação de um projeto pela prefeitura, seja na forma de favelas, aglomerados habitacionais com propriedade fundiária irregular, em sua maioria com infraestrutura deficiente, além de, muitas vezes, serem instalados precariamente em terrenos que oferecem risco à função de moradia, como em fundos de vale e em encostas com elevado nível de inclinação (GRAZIA; LEÃO JÚNIOR, 2002; MARICATO, 2003).

Embora mais comum, a ocupação de terrenos com alta declividade e marginais a cursos e corpos d'água não se dá, no espaço urbano, apenas na forma de usos residenciais. Não é raro encontrarmos em cidades este tipo de terreno sendo utilizado para fins agropecuários (caso de chácaras e áreas de cultivo incrustadas nos interstícios da malha urbana) e até mesmo com unidades industriais.

Em que pesem as diferenças entre si, todos estes usos, além de conflitarem a legislação ambiental e de parcelamento da terra urbana, podem desencadear danos socioambientais. A ocupação de margens de cursos d'água e fundos de vale por áreas residenciais, industriais e agrícolas, auxilia na geração de uma cadeia de impactos negativos, entre os quais se pode mencionar, conforme Amorim e Cordeiro (2005), a remoção da vegetação ciliar e a consequente perda de biodiversidade (a qual, frequentemente, já é escassa nas cidades), e a intensificação de processos erosivos nas encostas, aumentando o volume de sedimentos carreados para os cursos d'água e intensificando o risco de escorregamentos das terras ocupadas. Com isso, há também o aumento do escoamento superficial e o assoreamento do leito da drenagem, elevando as possibilidades da ocorrência de inundações e enchentes. Essas, por sua vez, também podem ocasionar sensíveis problemas à população ocupante, desde a proliferação de doenças como leptospirose e verminoses diversas, como a destruição de moradias e bens dos moradores, colocando a integridade física e a vida dos habitantes em risco.

Outro sério problema comumente associado à ocupação residencial das proximidades da rede de drenagem é a poluição e contaminação das águas. Frente à precariedade sanitária vigente em muitas destas ocupações, tanto o esgoto como, em alguns casos, o lixo produzido no local são lançados diretamente nos cursos d'água, comprometendo a qualidade da água superficial e também da subterrânea, podendo prejudicar o abastecimento da cidade (BRASIL, 2003).

Tendo em vista a comum ocorrência desses danos, Grostein $(2001$, p. 16) aponta que " [...] A escala e a frequência com que estes fenômenos se multiplicam nas cidades revelam a relação estrutural entre os processos e padrões de expansão urbana da cidade informal e o agravamento dos problemas socioambientais". Embora a produção de tais impactos negativos não esteja vinculada 
exclusivamente às práticas das populações mais empobrecidas, como procurou-se demonstrar, quem mais sofre com esse processo é a população pobre assentada nas submoradias irregulares, já que esta, além de já sofrer com a falta de acesso a serviços de infraestrutura básica, tem dificuldades para tomar atitudes defensivas diante da insuficiência de renda e das políticas públicas ineficientes.

A discussão apresentada acima deixa claro, portanto, que os atributos físicos do terreno constituem uma importante variável no processo de produção do espaço urbano. Ao favorecerem ou dificultarem a ocupação residencial e a implantação de atividades produtivas, ao serem tomados como amenidades ambientais ou como entraves à promoção imobiliária, ao valorizarem os terrenos ou levarem à sua retenção pelo Estado, tais atributos contribuem, em maior ou menor grau, para a consolidação de relações diferenciais de apropriação e uso das terras urbanas, sendo tais apropriações mais ou menos distintas de acordo com a estrutura da sociedade em classes e da correlação entre forças presente em seu bojo.

É neste contexto que se pode falar de uma topografia social no âmbito da produção do espaço urbano, tomando de empréstimo o termo cunhado por Aldaíza Sposati. Esta assistente social, no entanto, utiliza a expressão para se referir especificamente aos desníveis sociais, tanto em termos de poder aquisitivo da população, como, e principalmente, em relação à oferta de serviços públicos, sendo as "feições" e os "desníveis" topográficos associados a desigualdades socioespaciais urbanas, como evidenciam as citações a seguir:

[...] existe na cidade uma topografia social, que é construída sobre a topografia da natureza e que tem os seus acidentes, o seu desenho, talvez mais como as dunas do que como as montanhas ou as rochas, no sentido de existirem ventos que movimentam essa topografia social. (SPOSATI et al., 2004, p. 89)

[...] Os vales e montanhas sociais criam outras densidades na topografia social dos territórios dos pedaços da cidade que precisam ser analisados. (SPOSATI, 2001, p. 139)

A perspectiva da topografia social apresentada por Sposati traz como principal contribuição a ênfase conferida às desigualdades socioespaciais urbanas, porém a ideia de topografia aparece muito mais em sentido conotativo, numa analogia entre assimetrias sociais e desníveis de terreno. Propõe-se aqui utilizar o termo numa acepção mais ampla, apreendendo a ideia de topografia em um sentido denotativo, concreto. Procura-se vincular a dimensão da produção socialmente diferencial da cidade - a topografia social no sentido colocado pela autora - à dimensão da natureza, visando enfatizar o papel do sítio urbano, isto é, da configuração topográfica propriamente dita, na gênese das disparidades socioambientais e da estruturação do espaço urbano de um modo geral.

Assim, na perspectiva ora adotada, a topografia social se refere à apropriação diferencial do relevo (a "topografia natural") para a implementação de diversos tipos de usos da terra (com fins residenciais, econômicos ou de outra natureza), os quais em conjunto engendram uma organização espacial urbana desigual e, por vezes, segregada, sob os pontos de vista social e ambiental. Deriva, portanto, utilizando acepção de Santos (1993, p. 96), da “[...] superposição de um sítio social ao sítio natural", que é desencadeada no movimento de produção da cidade.

A configuração do sítio natural e sobretudo sua apropriação e uso, são, portanto, aspectos de suma importância a serem considerados na análise geográfica de determinadas cidades. É o caso, por exemplo, de Ponta Grossa, cuja topografia social será foco de análise a partir da próxima seção.

\section{ESTUDO DE CASO: A Topografia Social Urbana de Ponta Grossa (PR)}

\section{Aspectos Metodológicos}

Doravante será apresentada a análise empírica da topografia social urbana, a partir da realidade observada na cidade de Ponta Grossa. A metodologia adotada na pesquisa consistiu no estudo e revisão de bibliografia específica e no emprego de geotecnologias para subsidiar a análise das 
principais condicionantes da configuração topográfica sobre a expansão horizontal da área urbanizada, bem como sobre a espacialização dos segmentos sociais e sobre os padrões atuais de uso e ocupação da terra urbana.

Realizou-se a compilação de diversos dados estatísticos e cartográficos, os quais foram estruturados na forma de uma base de dados georreferenciados construída a partir do encaminhamento metodológico apresentado por Zeiler (1999). Os modelos tridimensionais de superfície e alguns dos mapas temáticos apresentados adiante foram construídos a partir de procedimentos geocartográficos específicos.

Para o mapeamento da expansão horizontal urbana fez-se a interpretação visual das áreas urbanizadas existentes no município a partir de imagens aéreas de diferentes momentos históricos. Para os anos de 1960 e 1980 foram utilizadas fotografias aéreas com escalas aproximadas de 1:70.000 e 1:25.000 respectivamente. Em relação aos demais anos, o mapeamento teve como base imagens dos satélites Landsat 5 e 7 (resolução espacial de trinta metros) para os anos de 1990 e 2000, e imagens CBERS/CCD para 2008 (resolução espacial de vinte metros).

O mapa de tipos de usos irregulares da terra urbana foi construído utilizando dados de 2005 e empregando procedimentos de geoprocessamento, conforme metodologia proposta por Matias e Nascimento (2006):

a) delimitação de áreas com restrições de uso segundo a legislação federal em vigor: faixas de terras marginais à rede de drenagem (cursos e corpos d'água) e encostas com declividade igual ou superior a 30\% ("Código Florestal”, leis n 4.771/1965 e 7.803/1989, e lei de parcelamento do solo urbano, $n^{\circ} 6.766 / 1979$ )

b) sobreposição das informações de uso e ocupação da terra às áreas destinadas à preservação permanente delimitadas.

Por sua vez, os modelos tridimensionais do terreno, que foram utilizados como base para a produção do mapa hipsométrico e para a visualização de dados socioeconômicos em terceira dimensão, foram elaborados a partir de dados digitais de pontos cotados e de curvas de níveis com equidistância de cinco metros, utilizando o software ArcGIS 3D Analyst (ESRI, 2008). A metodologia da pesquisa contou ainda com a realização de trabalhos de campo, efetuados em diversos momentos entre os anos de 2007 e 2011, para observações in loco e registro fotográfico-documental da configuração socioespacial da cidade de Ponta Grossa.

\section{A Cidade: principais bases histórico-geográficas}

O município de Ponta Grossa está localização na mesorregião Centro-oriental do estado do Paraná e seu centro urbano situa-se a aproximadamente 118 quilômetros da capital estadual (Figura 1).

Desde o princípio do século XX, Ponta Grossa se destaca como um dos principais centros urbanos do interior do Paraná devido à sua importância enquanto entreposto comercial e entroncamento ferroviário, que viabilizava a produção e a exportação principalmente de madeira e erva-mate, assim como impulsionava a ampliação de seu setor terciário (MONASTIRSKY, 2001). Com o dinamismo de sua economia, o município se consolida como um importante polo de atração de migrantes, de modo que já no princípio do século XX, diferentemente da maior parte dos municípios paranaenses de porte semelhante, Ponta Grossa apresentava a maior parcela de sua população residindo na cidade e trabalhando em atividades eminentemente urbanas (PAULA, 1993). E a conjugação entre crescimento econômico e populacional aos poucos foi também estimulando o crescimento horizontal da cidade, sobretudo por meio da criação de novas áreas residenciais.

Até os anos 1980, a cidade experimentou um elevado crescimento demográfico, multiplicando em quase seis vezes a sua população (Tabela 1). Mas até a década de 1960 também ocorria, em menor proporção, um crescimento da população rural e o crescimento vegetativo ainda contribuía com parcela importante do incremento populacional urbano. A partir de meados desta década, contudo, o crescimento populacional urbano se eleva em relação ao decênio anterior devido ao 
expressivo êxodo rural que se instaura, impulsionado pela modernização da agricultura no estado do Paraná (MORO, 2000). Tal processo desencadeou profundas modificações na estrutura social da cidade, pois, diferentemente das migrações anteriores, empurrou um maciço contingente de pessoas empobrecidas e com baixa escolaridade para o espaço urbano em busca de trabalho e de moradia (LÖWEN, 1990).

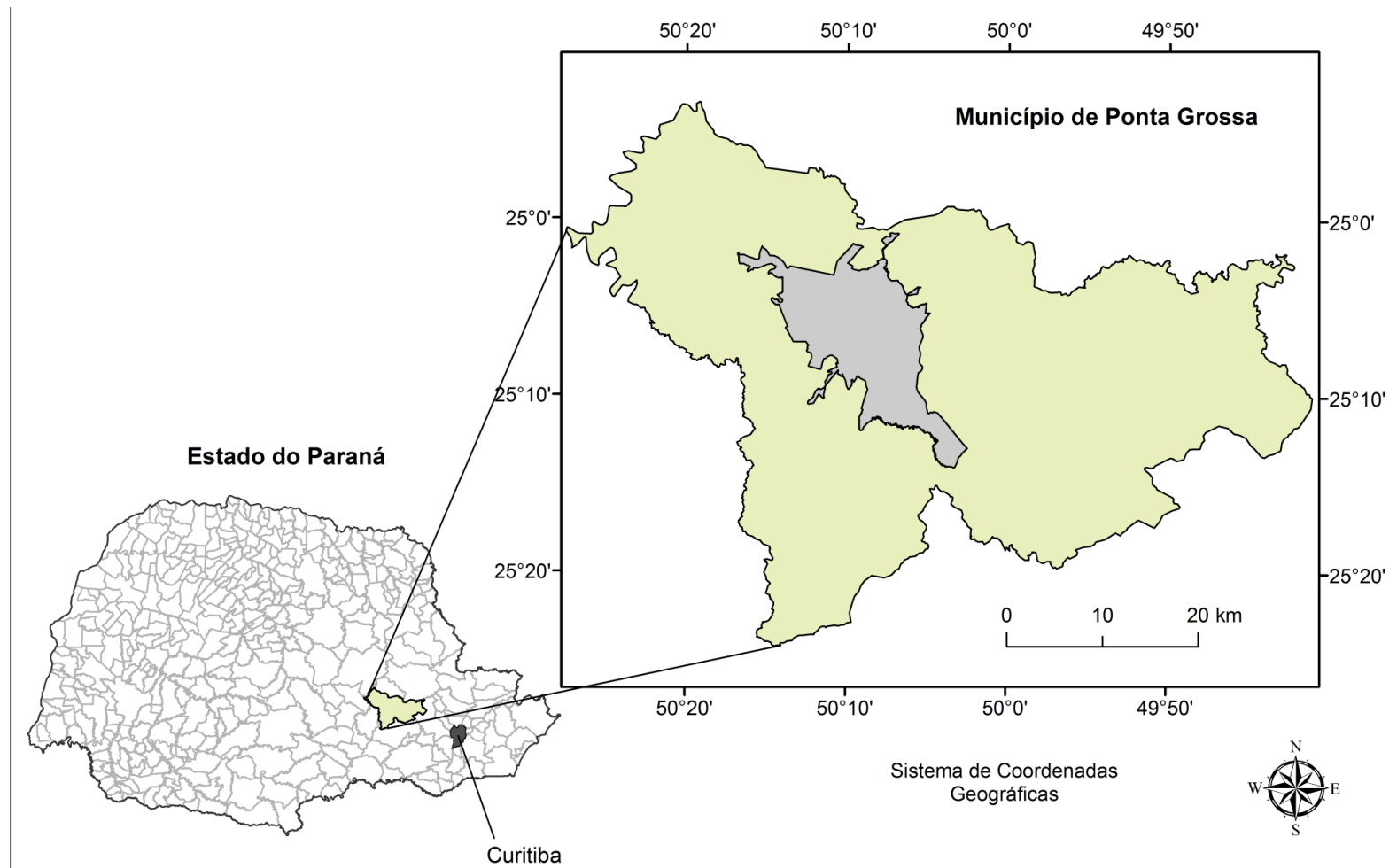

Figura 1 - Localização do município e da área urbana de Ponta Grossa no estado do Paraná. Fontes: IBGE (2007); Prefeitura Municipal de Ponta Grossa (perímetro urbano 2007).

A industrialização de Ponta Grossa, iniciada no começo dos anos 1970, também atraiu um grande número de migrantes para a cidade, motivados pela expectativa de conseguir emprego nas indústrias nacionais e estrangeiras (em sua maioria, ligadas ao complexo agroexportador da soja) recém-instaladas (PAULA, 1993). Além disso, esta expansão do setor industrial modificou o perfil da cidade na sua estrutura interna, com a construção de praças e investimentos em pavimentação de ruas e melhorias da iluminação pública nos bairros (SCHEFFER, 2003), o que acabou afetando a dinâmica de valorização da terra na cidade e contribuindo para a intensificação da especulação imobiliária.

Tabela 1 - População urbana e crescimento relativo no município de Ponta Grossa (1940 a 2010)

\begin{tabular}{l|c|c}
\hline Ano & $\begin{array}{c}\text { População } \\
\text { urbana }\end{array}$ & $\begin{array}{c}\text { Crescimento } \\
\text { relativo (\%) }\end{array}$ \\
\hline 1940 & 30.220 & \\
1950 & 43.486 & 43,9 \\
\hline 1960 & 78.557 & 80,6 \\
\hline 1970 & 113.074 & 43,9 \\
\hline 1980 & 172.946 & 52,9 \\
\hline 1991 & 221.671 & 28,2 \\
2000 & 266.683 & 20,3 \\
2010 & 304.733 & 14,3 \\
\hline
\end{tabular}

Fonte: IBGE (Censos demográficos 1940-2010). 
A partir dos anos 1980, as constantes crises econômicas pelas quais passou o país frearam a industrialização e o desenvolvimento econômico de Ponta Grossa. As migrações de origem rural também arrefeceram, mas diante dos impactos ainda mais severos sofridos pelas economias de outras regiões do Paraná (em especial, por municípios vizinhos a Ponta Grossa e da Mesorregião Sudeste Paranaense), a cidade passou a receber também migrantes de outras áreas urbanas do estado, os quais contribuíram para manter elevadas as taxas de crescimento demográfico no município (vide Tabela 1).

Estes eventos criaram ao longo do tempo as condições que levaram a um processo de expansão horizontal da cidade bastante intenso e com crescente divisão espacial de usos e segregação de segmentos sociais, no qual a configuração da topografia teve um papel importante. Criou-se uma demanda potencial de terras para consumo urbano, incentivando a ação especulativa de diversos proprietários fundiários, os quais passaram a promover o loteamento de diversas glebas, inclusive em áreas atualmente consideradas impróprias à ocupação urbana, especialmente em encostas com acentuada declividade. Além disso, a expansão horizontal, ao inflacionar os preços do solo, ampliou contraditoriamente as dificuldades de acesso à terra e à moradia enfrentadas pelos contingentes de migrantes pobres que rumaram para a cidade, aumentando assim a ocupação irregular de áreas não edificáveis para fins de moradia (NASCIMENTO; MATIAS, 2011).

A evolução desta dinâmica de expansão horizontal e ocupação do espaço urbano, bem como as principais características da topografia social da cidade de Ponta Grossa, são foco de análise na seção a seguir.

\section{A Evolução Urbana e a Produção da Topografia Social}

Como já foi dito anteriormente, o desenho e a forma de uma cidade dependem, num primeiro momento, basicamente das condições topográficas, e a partir de então, num momento posterior, se sobressaem as forças sociais, ainda condicionadas, em maior ou menor grau, pelos aspectos do relevo. No caso de Ponta Grossa, a evolução da expansão horizontal e da respectiva ocupação do espaço urbano resulta de um conjunto de forças sociais, cuja ação foi influenciada pelas características particulares de seu sítio (LÖWEN SAHR, 2001).

O centro da cidade localiza-se num alto topográfico do qual divergem radialmente vários cursos d'água, sendo que o crescimento horizontal da malha urbana se deu, sobretudo, a partir dos divisores topográficos. As enormes disparidades hipsométricas e a densa rede de drenagem, existentes na cidade, caracterizam o sítio urbano como uma superfície repleta de vales, muitos dos quais constituídos de encostas com declividades acentuadas (Figura 2). Tais características conferem ao sítio local um caráter bastante heterogêneo no que diz respeito às possibilidades de ocupação, com a ocorrência de amplas áreas inadequadas para a construção de edificações. Este fato interfere na dinâmica de organização do espaço urbano na medida em que certas áreas são mais bem valorizadas no mercado imobiliário, ao passo que outras são desprezadas e/ou retidas pelo Estado para fins de proteção ambiental.

Pode-se definir algumas etapas marcantes na evolução da expansão urbana em Ponta Grossa. Até o final da década de 1910, o crescimento da área urbanizada ocorria sobretudo ao redor do alto topográfico onde a cidade teve origem, área esta que atualmente corresponde ao centro urbano. A partir dos anos 1920, a cidade começou a se expandir radialmente ao longo dos principais interflúvios, com destaque para a implantação de importantes loteamentos nos eixos sul (bairro Oficinas) e leste (bairro Uvaranas), seguindo a estrada de ferro que, à época, cruzava a área central da cidade (LÖWEN SAHR, 2001).

Nos vinte anos seguintes, ao mesmo tempo em que o centro se consolidava como local de moradia das classes de mais alta renda, dotado de praticamente toda a infraestrutura necessária (pavimentação, telefone etc.) e dos melhores serviços da cidade, a periferia foi se expandindo com a construção de loteamentos (CHAMMA, 1988; CHAVES et al., 2001). Na década de 1930 pros- 
seguiu a expansão radial da cidade ao longo dos demais espigões do relevo, nas direções norte, noroeste e leste, dando origem, respectivamente, aos atuais bairros Órfãs, Nova Rússia e Ronda.

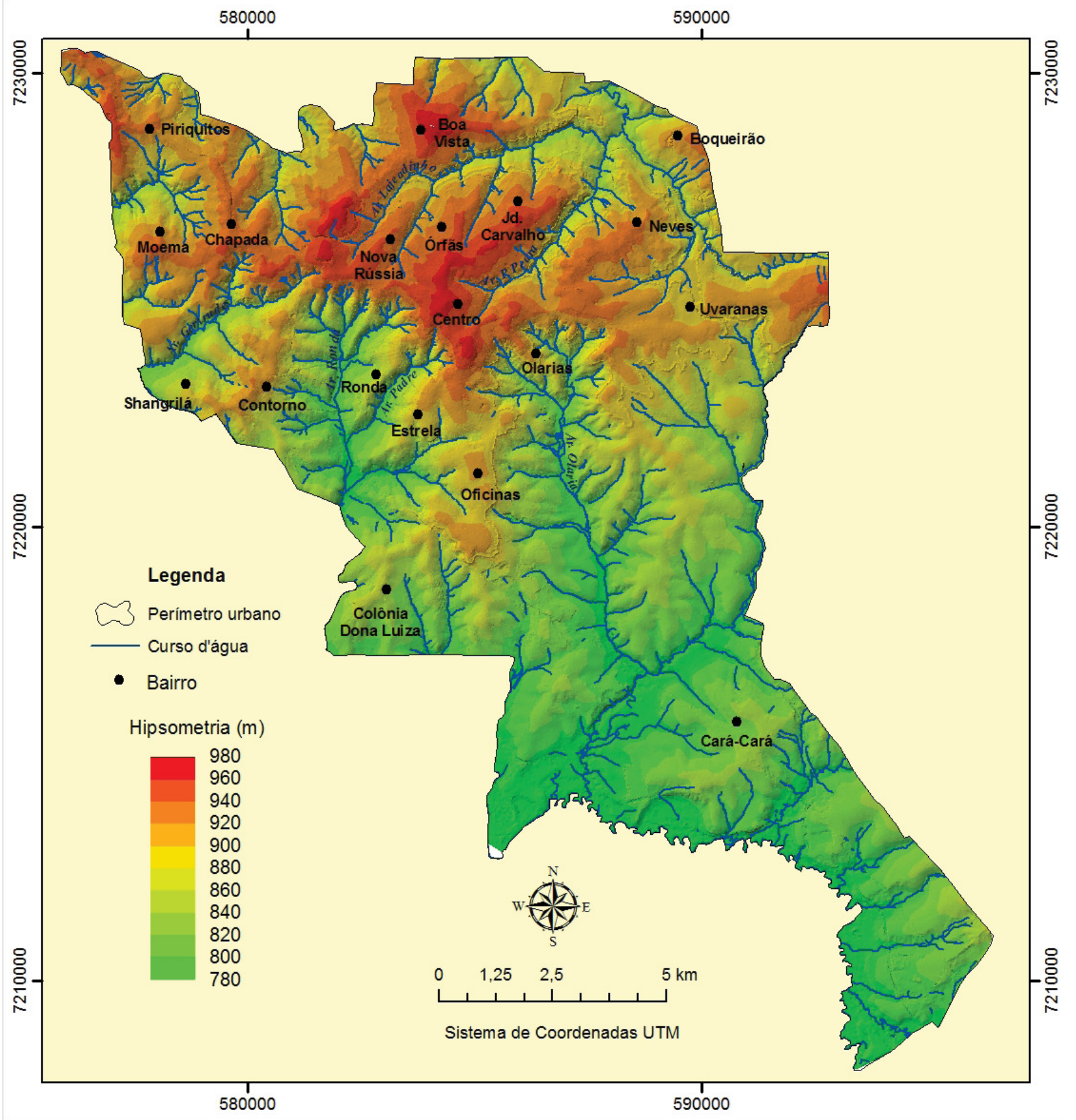

Figura 2 - Hipsometria e rede de drenagem da área urbana de Ponta Grossa.

Fonte: Prefeitura Municipal de Ponta Grossa (Base cartográfica 2001, adaptada).

O padrão espacial de expansão urbana, que seguia pelos divisores topográficos, passou a sofrer alterações importantes a partir da década de 1940. Neste decênio ocorreu uma destacada expansão urbana na direção sudoeste do centro, com a ocupação, por meio de loteamentos, de terrenos acidentados - algo inédito na história da cidade - nas proximidades das cabeceiras do arroio da Olaria (LÖWEN SAHR, 2001) (vide Figuras 2 e 3).

Nas décadas de 1950 e 1960, o tecido urbano pontagrossense sofreu expressiva ampliação, impulsionada por um forte processo de especulação fundiária empreendido a partir de então. A periferia urbana foi significativamente estendida com a produção de diversos loteamentos longínquos, 
alguns separados da malha urbana contínua por enormes glebas não loteadas. De acordo com Paula (1993), dois fatores principais incentivaram a implantação de tais loteamentos:

a) a inexistência de uma legislação urbana mais rigorosa quanto ao parcelamento da terra para fins urbanos, que estabelecesse parâmetros urbanísticos (metragens de lotes, dotação mínima de infraestrutura, reserva de áreas para equipamentos públicos etc.) e ambientais (como as áreas de proteção permanente) a serem observados, além de punições a serem aplicadas quando de seu descumprimento;

b) as constantes ampliações do perímetro urbano, as quais multiplicaram a área urbana em quase nove vezes entre 1950 e 2007, sendo que os maiores aumentos em termos percentuais ocorreram naquelas duas décadas.

Como se pode observar no mapa a seguir (Figura 3), em 1960 a área urbanizada se limitava à atual área central, acrescida de eixos de ocupação ao longo dos principais interflúvios, seguindo as avenidas Carlos Cavalcanti, Monteiro Lobato, Dom Pedro II e Visconde de Mauá. Em relação à ocupação do sítio urbano, cabe destacar o aumento da ocupação urbana nas cabeceiras dos principais cursos d'água urbanos (arroios Pilão de Pedra, Olaria, do Padre, Ronda e Lajeadinho), todas nas proximidades da área central. O vale mais densamente ocupado era o do arroio da Ronda, entre as avenidas Dom Pedro II e Visconde de Taunay, área esta recortada por pequenos cursos d'água e com encostas bastante íngremes (vide Figura 2), sobre as quais foram implantados diversos loteamentos clandestinos e precários. A maioria das residências destes loteamentos permanece irregular até os dias atuais, tanto do ponto de vista ambiental como em relação à propriedade jurídica da terra.

No decorrer das décadas de 1960 e 1970, têm-se a implantação de diversos loteamentos afastados da malha urbana contínua, o que contribuiu para um espraiamento da área urbanizada, sobretudo nas direções norte, sudoeste e sul (Figura 3).

Com a criação da lei federal $n^{\circ} 6.766$ de 1979, bem como, em âmbito municipal, das leis $n^{\circ}$ 2.839 de 1976 e $\mathrm{n}^{\circ} 4.840$ de 1992 , os projetos de loteamento tiveram que se adequar a parâmetros urbanísticos mais rígidos, sobretudo em relação à dotação de infraestrutura. A ocupação do espaço passou também a ter que se adequar a uma série de normas de zoneamento, definidas pelas leis municipais $\mathrm{n}^{\circ} 2.016$ de $1968, \mathrm{n}^{\circ} 2.840$ de 1976 e $\mathrm{n}^{\circ} 4.856$ de 1992 . Com isso, a partir dos anos 1980, diminuiu a implantação de loteamentos afastados da malha contínua. Porém, isso não reduziu o ritmo da expansão horizontal da cidade, verificando-se principalmente a urbanização de terras situadas entre terrenos periféricos já parcelados.

Finalmente, a partir dos anos 1990, verificou-se uma ampliação da ocupação urbana a oeste no vale do arroio Gertrudes, também com o predomínio de áreas residenciais abrigando populações de baixa renda, e a sudoeste, na porção mais plana da bacia do Ronda, sendo a ocupação deste último predominantemente na forma de áreas habitacionais e de chácaras de recreio. Por sua vez, a destacada expansão da área urbanizada no sentido sudeste é particularmente explicada pela densificação da ocupação na área do Distrito Industrial, instalado ao longo da Rodovia BR-376. 


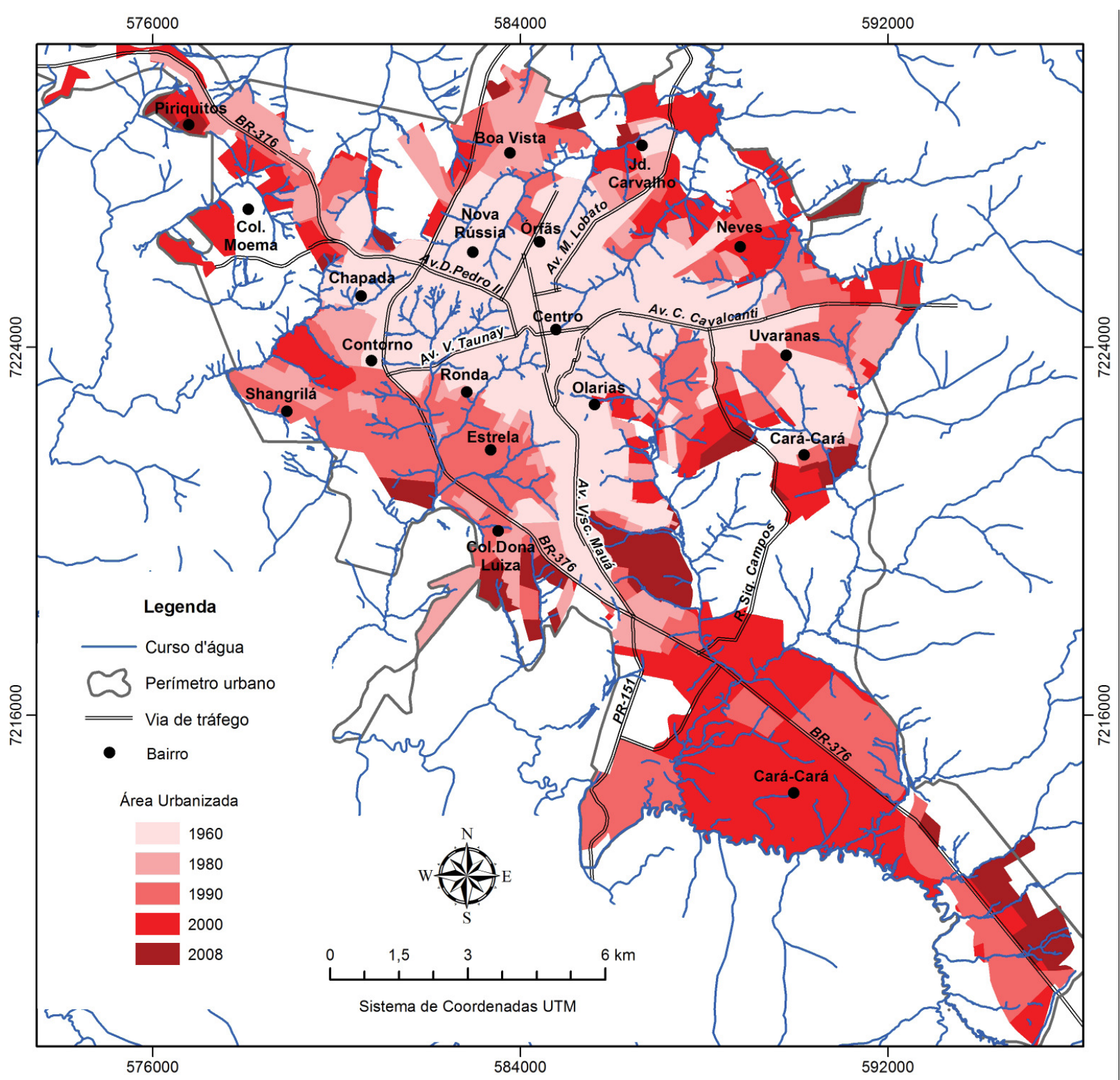

Figura 3 - Evolução da área urbanizada em Ponta Grossa no período de 1960 a 2008.

Fontes - Interpretação de fotografias aéreas (1960/1980) e imagens de satélite (1990/2000/2008).

Com o avanço do processo de expansão urbana, aos poucos se consolidou um padrão contraditório de ocupação e uso do espaço urbano, em que a especulação e a subocupação de diversas áreas, convivem com o aumento de usos irregulares da terra em áreas de proteção ambiental permanente e das ocupações habitacionais em áreas inadequadas à função de moradia.

Ao observarmos os padrões sociais de ocupação do espaço urbano em Ponta Grossa, um primeiro aspecto que chama a atenção é a estreita correlação existente entre as populações segundo seu nível de renda e as condições topográficas do local onde estão. A figura 4 apresenta um modelo tridimensional da área urbana de Ponta Grossa, onde, na imagem de satélite sobreposta, é possível observar que o tecido urbano se estendeu ocupando a maioria das encostas inclinadas e dos fundos de vale, principalmente nas proximidades do centro da cidade. Todavia, ao efetuar-se a sobreposição dos setores censitários com dados sobre percentuais de chefes de família com rendimento de até um salário mínimo, constata-se que, além de a participação destes segmentos populacionais ser maior na periferia urbana, estes percentuais são também mais elevados nas áreas com topografia mais acidentada, algumas destas, inclusive, nas proximidades do centro urbano, casos dos bairros Olarias, Ronda e Nova Rússia, situados respectivamente a sudeste, sudoeste e oeste da área central. 
Por outro lado, as áreas com topografia mais suave, principalmente os divisores de águas, que correspondem aos locais onde a cidade se iniciou e onde foram implantadas as principais vias de tráfego, tornaram-se "nobres", sendo atualmente localizações que concentram segmentos de renda média e alta, além de usos urbanos não-residenciais, como estabelecimentos comerciais e de prestação de serviços (Figura 4).

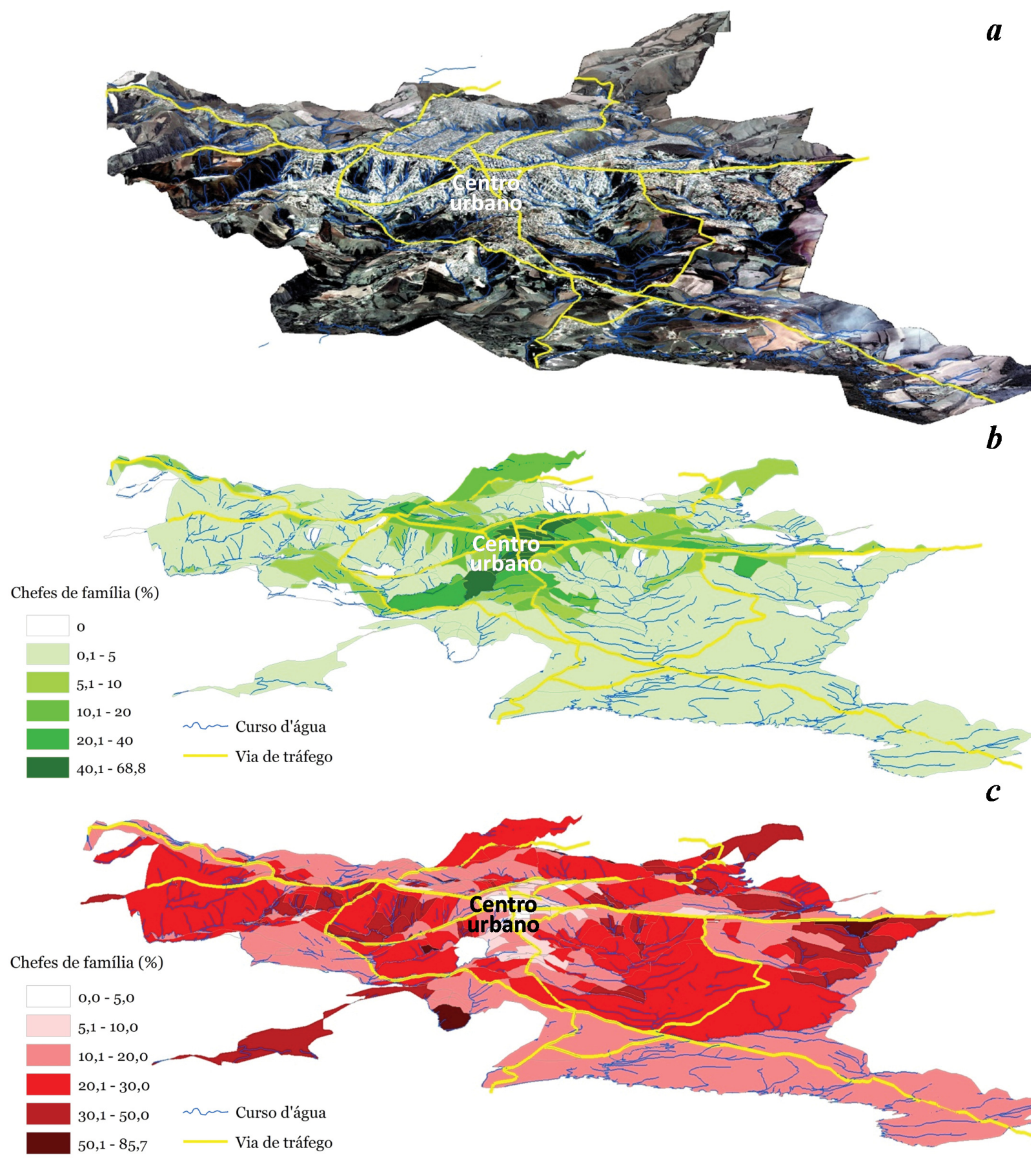

Figura 4 - Vistas oblíquas no sentido sul-norte, de um modelo digital de elevação (exagero vertical de 4 vezes) da área urbana de Ponta Grossa: a) sobreposição de imagem de satélite, de 2004; b) representação, por setores censitários urbanos, do percentual de chefes de família com rendimento igual ou superior a dez salários mínimos; c) percentual de chefes de família com rendimento de até um salário mínimo.

Fontes: IBGE (Censo demográfico 2000);

Prefeitura Municipal de Ponta Grossa (base cartográfica 2001, modificada). 
Ao se examinar a distribuição de determinados serviços que têm uma oferta heterogênea na cidade, como o esgotamento sanitário, constata-se uma divisão social do espaço semelhante à relatada acima. Fazendo-se a sobreposição, ao mesmo modelo tridimensional, dos percentuais de domicílios sem rede pública de esgoto nos setores censitários (Figura 5), pode-se observar a grande discrepância na oferta deste serviço no espaço da cidade, sendo novamente as áreas de topografia mais suavizada (área central e eixos viários principais) as mais privilegiadas, isto é, com os maiores percentuais de domicílios servidos pelo esgotamento sanitário público.

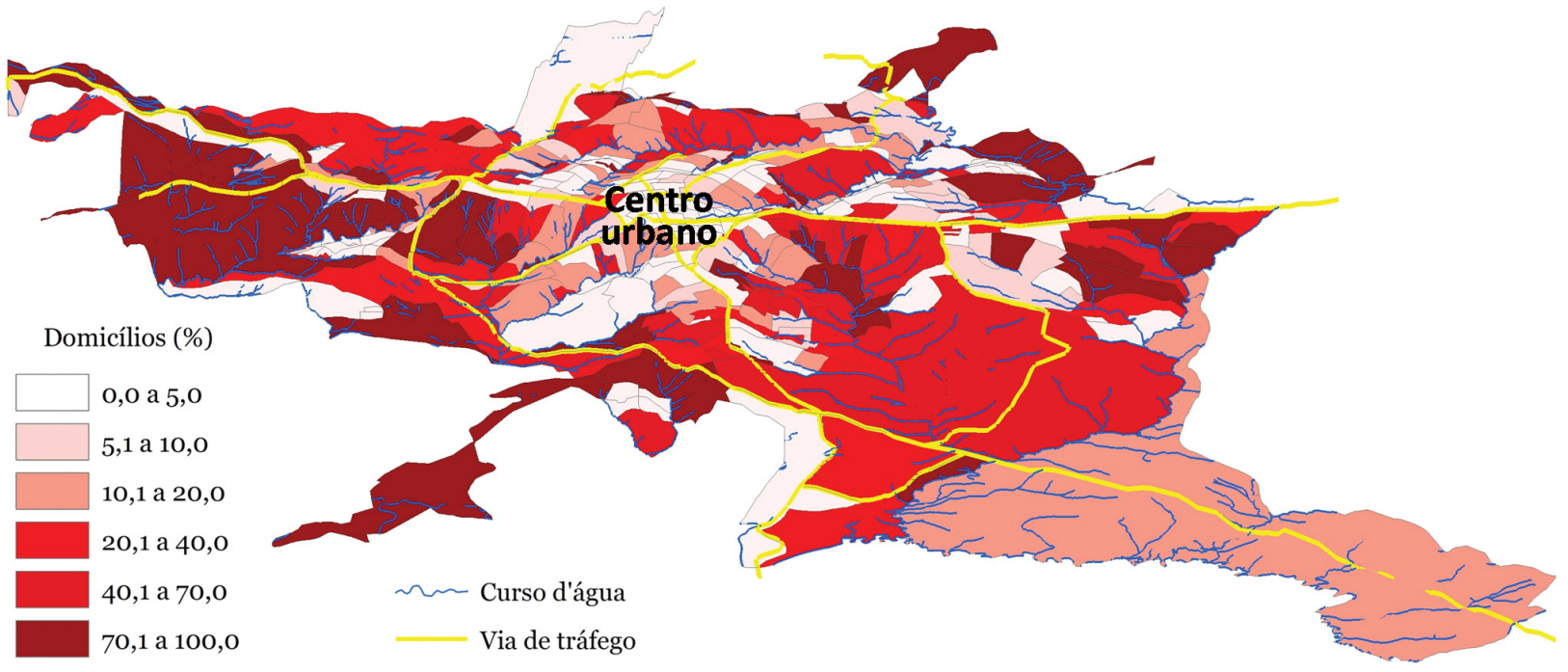

Figura 5 - Representação, sobre modelo digital de elevação (exagero vertical de 4 vezes), do percentual de domicílios sem rede pública de esgoto, em setores censitários urbanos (2000). Fontes: IBGE (Censo demográfico 2000); Prefeitura Municipal de Ponta Grossa (base cartográfica 2001, modificada).

Esta configuração espacial é a principal característica daquilo que estamos chamando de topografia social. No caso, as porções do espaço que apresentam as características topográficas mais desfavoráveis à ocupação e à exploração imobiliária - fundos de vales íngremes e encostas com elevado grau de declividade, todos sem elementos naturais aprazíveis -, por apresentarem maiores restrições físico-ambientais e jurídicas do que outras áreas do perímetro urbano, acabam concentrando segmentos empobrecidos da população. E, além disso, a menor oferta de serviços públicos, como o esgotamento sanitário, tende a precarizar ainda mais as condições de vida das populações que vivem em tais localizações.

A fotografia exibida a seguir (Figura 6) ilustra esta ocupação socialmente diferencial do sítio urbano. Ao fundo, na porção superior da imagem, observa-se uma área habitacional adjacente ao centro da cidade (pertencente ao bairro Uvaranas), a qual se estende do alto topográfico do centro ao divisor topográfico do leste da cidade. Nota-se que na medida em que diminuem as cotas do terreno, os padrões sociais das habitações também diminuem, sendo, como já se disse, as áreas mais íngremes e os fundos de vales as localizações de maior concentração de populações de menor poder aquisitivo.

Outra característica do uso diferencial do sítio urbano, acentuada com o processo de expansão urbana, diz respeito ao estabelecimento, em áreas definidas como sendo de proteção permanente, de tipos de uso da terra conflitantes com a legislação ambiental e urbana. É possível encontrar em tais áreas de proteção não apenas usos residenciais irregulares, mas também outras formas incompatíveis de uso, como usos industriais, agrícolas, chácaras (onde houve a substituição da vegetação para o cultivo de hortas ou simplesmente para empreender usos relacionados ao lazer), além de áreas loteadas ou mantidas em especulação na forma de glebas, sem a devida vegetação campestre 

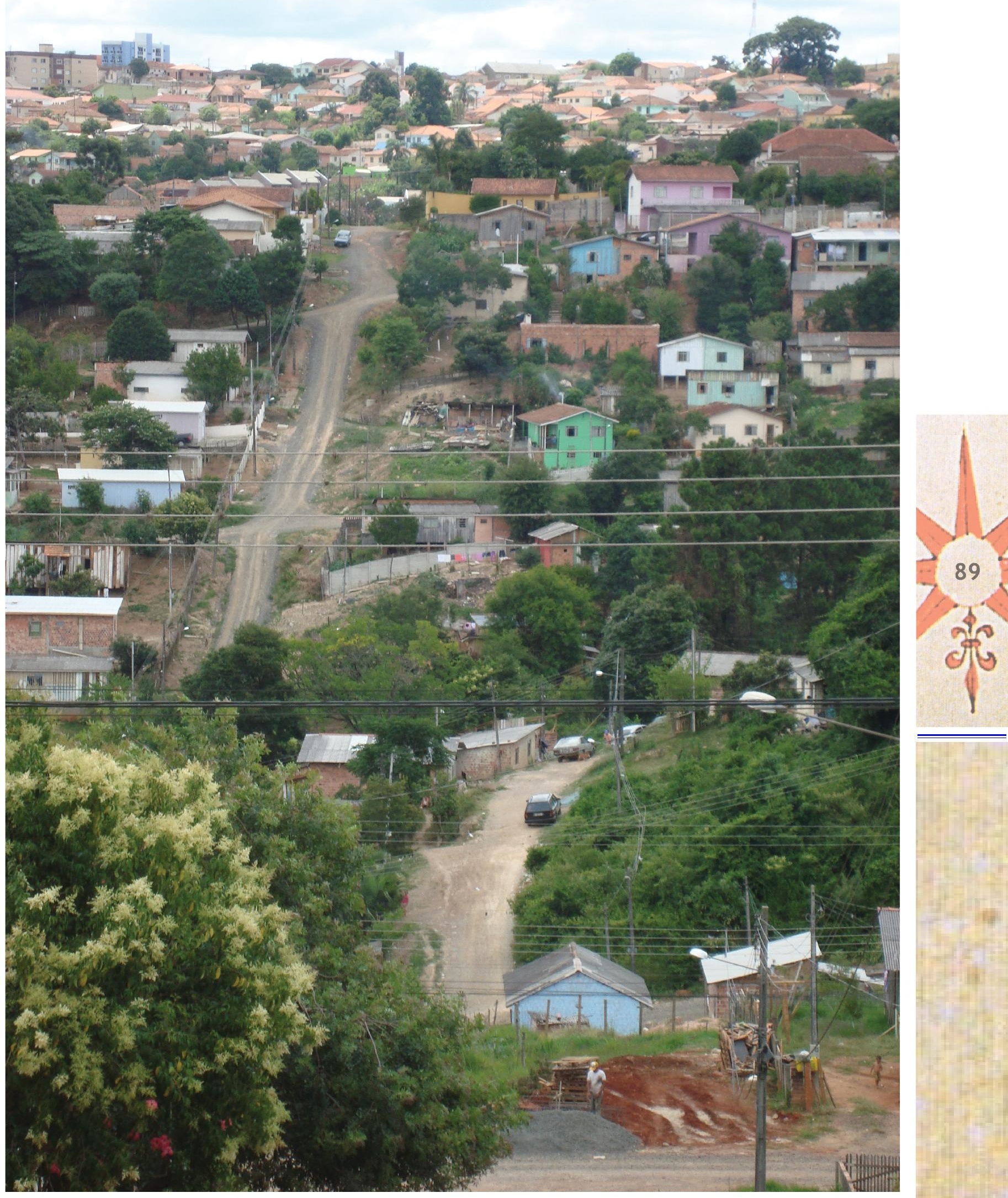

Figura 6 - Vista de áreas residenciais no bairro Uvaranas, nas proximidades do centro da cidade. Fonte: acervo particular do autor (2011) 
ou arbórea, no caso definidas como "desocupado" (Figura 7). Até mesmo alguns estabelecimentos comerciais (todos de pequeno porte) puderam ser identificados, principalmente nas encostas situadas no entorno do centro da cidade.

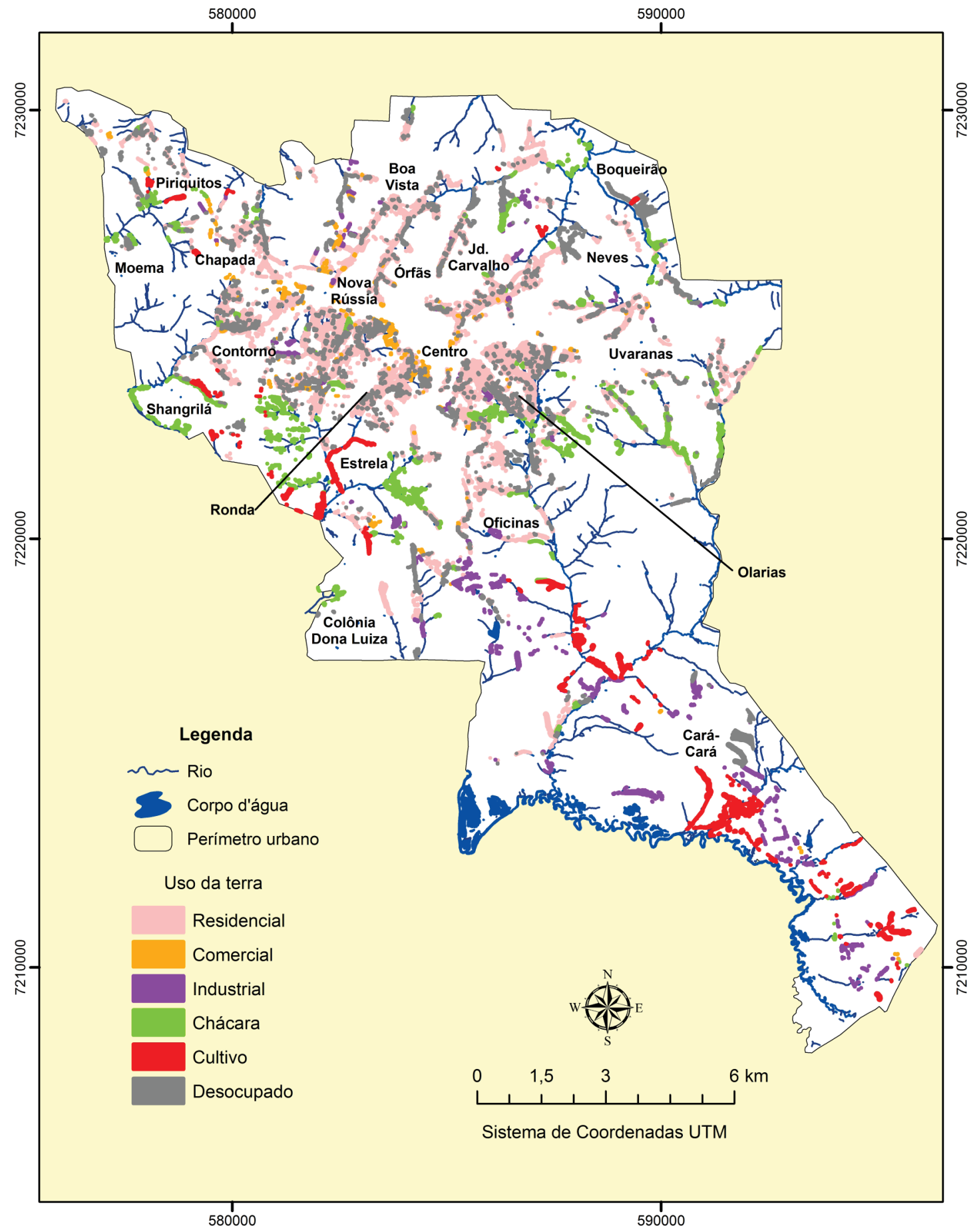

Figura 7 - Usos irregulares da terra em áreas de proteção permanente, área urbana de Ponta Grossa.

Fontes: Interpretação de imagem do satélite Ikonos (2004); pesquisa de campo (2004-2005);

Prefeitura Municipal de Ponta Grossa (base cartográfica 2001).

A topografia social urbana torna-se ainda mais evidente ao analisarmos os usos irregulares residenciais, já que grande parte destes corresponde a submoradias em favelas. Como se pode ver no mapa a seguir (Figura 8), em Ponta Grossa a maior parte das favelas está situada nas encostas 
íngremes e, principalmente, em fundos de vale, em terras de propriedade do Estado (vide Figuras 9 e 10). Trata-se de terras públicas, impróprias à ocupação para fins de moradia, mas que foram sendo paulatinamente ocupadas com a conivência do poder público municipal, à medida que este, ao longo do tempo, acabou viabilizando a expansão urbana especulativa em detrimento de uma gestão do uso do espaço urbano socialmente mais equânime, que atendesse as necessidades de acesso à terra e à cidade, das camadas mais pobres da população (LÖWEN, 1990; NASCIMENTO; MATIAS, 2011).

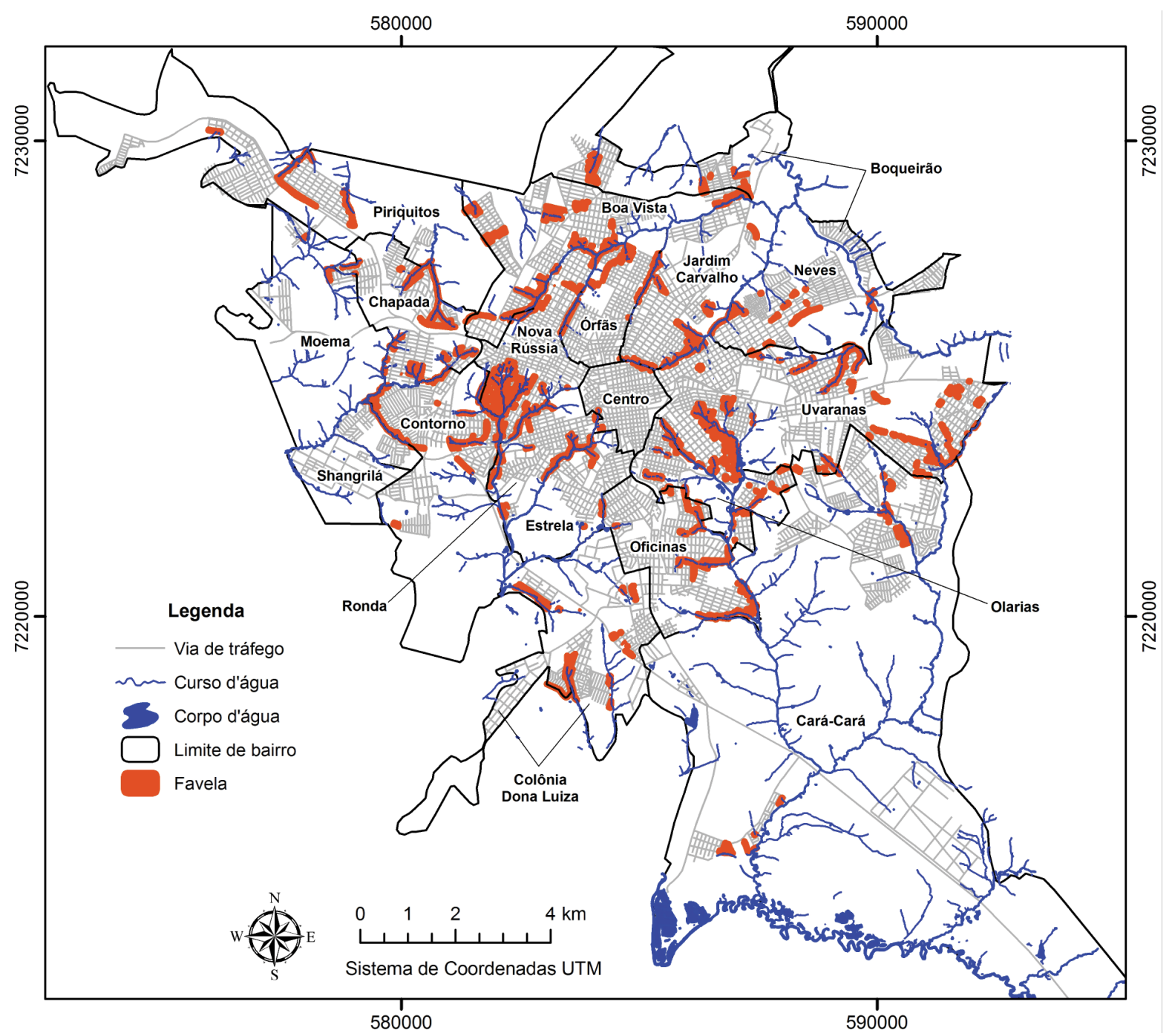

Figura 8 - Localização das favelas na cidade de Ponta Grossa.

Fontes: Prefeitura Municipal de Ponta Grossa (levantamento de ocupações irregulares, 2006; base cartográfica municipal, 2001, modificada); interpretação de imagens do satélite Ikonos (2004).

Em suma, como bem afirma Casseti (1991, p. 88),

Nas áreas urbanizadas, o processo de ocupação espacial é diferenciado, dependendo do valor econômico, ou ainda, definido pela ganância dos midas do capitalismo, que equiparam ao "padrão-ouro" o metro quadrado da terra. Assim, evidenciam-se os contrastes entre espigões e favelas, dos bairros ricos e bairros pobres, a ocupação de áreas estáveis e permissíveis, a implantação de edificações e ao mesmo tempo, ocupação de áreas de risco, consideradas "clandestinas" (fundos de vales ou vertentes de fortes declives). 


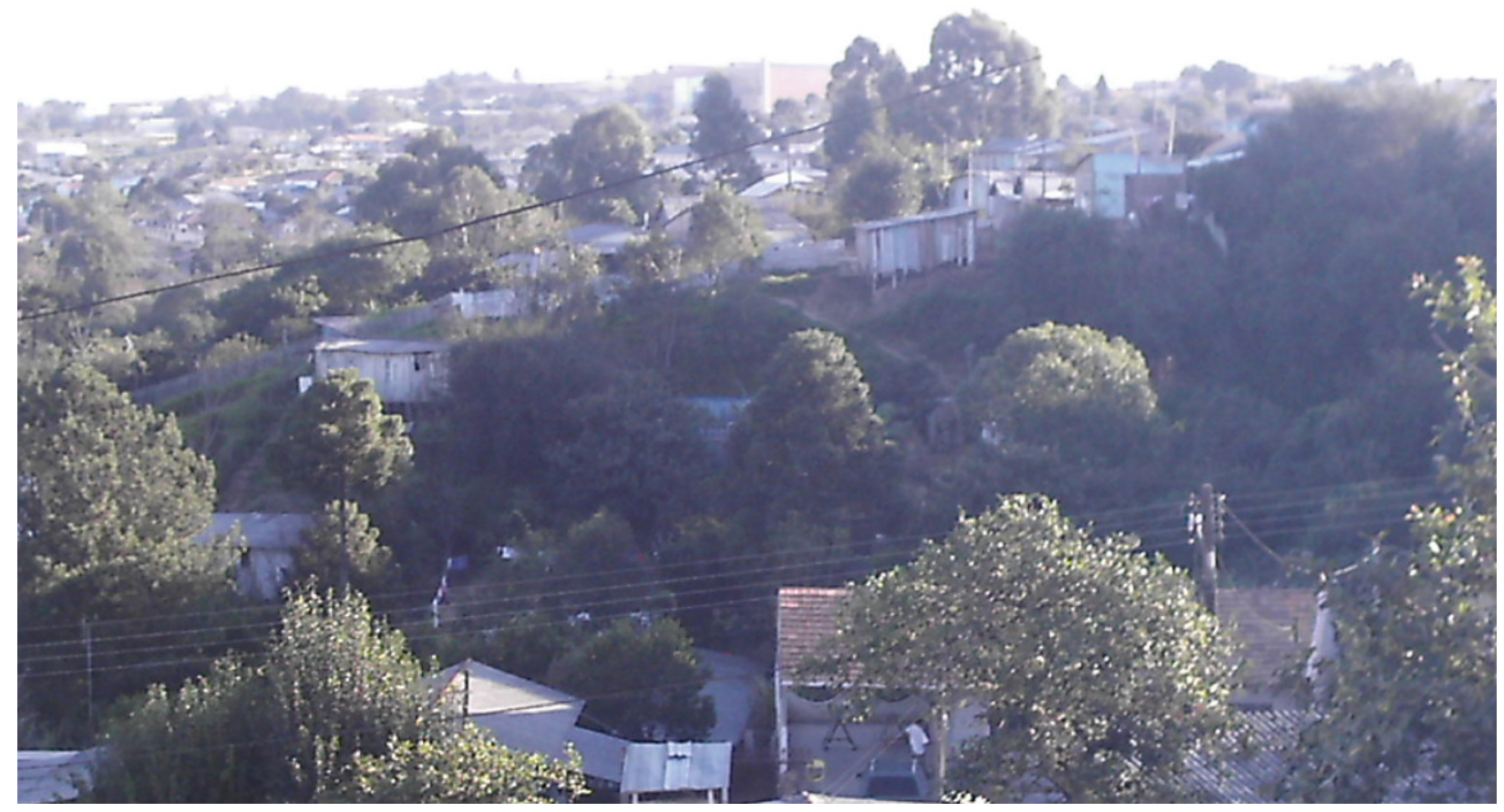

Figura 9 - Vista de uma favela em encosta com altas declividades (bairro Boa Vista). Fonte: acervo particular do autor (2007).

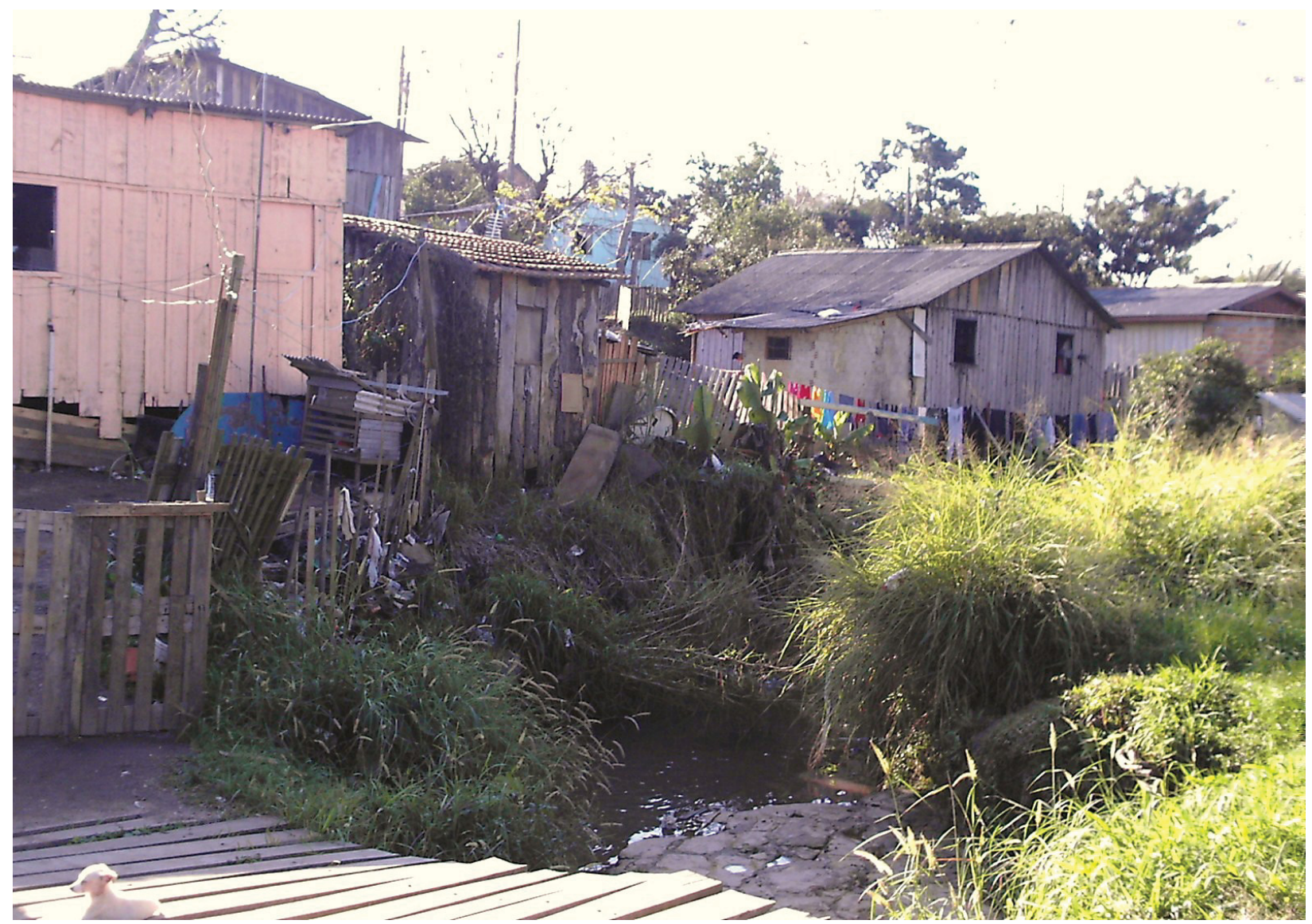

Figura 10 - Vista de uma favela situada ao lado de um córrego (bairro Nova Rússia). Fonte: acervo particular do autor (2007). 
Neste contexto, o processo de produção do espaço urbano em Ponta Grossa mostra-se contraditório sob os pontos de vista social e ambiental, haja vista que as diferenças ambientais (especialmente topográficas), ao serem mediadas pelas restrições da legislação, são incorporadas à dinâmica do valor da terra, fundindo-se às disparidades sociais. E à medida que este padrão de ocupação e uso do espaço avança, tal dinâmica tende a se acelerar, com as desigualdades sociais e ambientais aprofundando-se dialética e dramaticamente.

\section{CONSIDERAÇÕES FINAIS}

Neste ensaio, procurou-se, com o enfoque da topografia social, demonstrar e ressaltar a importância do sítio urbano na estruturação do espaço na cidade. Dependendo de suas características, a topografia e seus atributos poderão ser uma dimensão fundamental a ser considerada na análise da evolução socioespacial urbana, ao mediarem, em maior ou menor grau, a ação dos diversos agentes sociais produtores do espaço. Nesta via de análise, a topografia não deve apenas ser considerada per se, mas na relação sociedade-natureza que está no cerne da produção do espaço pelo homem, ou seja, no bojo da relação entre classes pela apropriação da natureza, dada, no caso do espaço urbano, por meio de localizações específicas que potencializam ou restringem a realização das atividades urbanas.

O exemplo da cidade de Ponta Grossa aqui apresentado, ilustra esta perspectiva de análise. A topografia condicionou a expansão horizontal da cidade e exerceu importante influência na distribuição dos segmentos sociais no espaço. Como resultado, atualmente a cidade apresenta uma estrutura espacial amplamente desigual e segregada em termos sociais e ambientais.

Finalmente, é importante ressaltar que esta topografia social urbana não incorre apenas numa distribuição desigual da população no sitio urbano, mas ela mesma influencia também a (re)produção do espaço. Em Ponta Grossa, danos ambientais como a erosão de encostas, poluição de rios e córregos a partir de efluentes e resíduos sólidos lançados nas águas, além da própria remoção da vegetação ciliar, tiveram crescimento expressivo com a ocupação e a prática de usos inadequados em áreas ambientalmente frágeis, como as margens de cursos d'água e as encostas íngremes, situação agravada pelas carências em infraestrutura básica (sobretudo de esgotamento sanitário).

Aos danos ambientais sobrepõe-se a questão social, que dialeticamente apresenta-se mais agravada nos espaços ambientalmente degradados. Sobretudo nas favelas e outras áreas de concentração de populações empobrecidas, estas, ao mesmo tempo em que são agentes das degradações, são também os que mais são vitimados por estas. No plano conjuntural, em função dos riscos de doenças, de acidentes como enchentes e deslizamentos de terras e outros malefícios que comprometem suas condições de vida. E acima de tudo, vítimas de uma lógica socialmente segregadora e excludente através da qual se dá a (re)produção do espaço urbano.

\section{REFERÊNCIA BIBLIOGRÁFICAS}

AMORIM, L. M. de; CORDEIRO, J. S. Impactos ambientais provocados pela ocupação antrópica de fundos de vale. Saneamento ambiental, [s. 1.], n. 111, p. 40-46, jan./fev. 2005.

BRASIL. Lei ${ }^{\circ} \mathbf{6 . 7 6 6}$, de 19 de dezembro de 1979. Dispõe sobre o parcelamento do solo urbano e dá outras providências. Disponível em: http://www.planalto.gov.br/ccivil_03/Leis/L6766.htm>. Acesso em: 30 jun. 2010.

BRASIL. Secretaria Nacional de Saneamento Ambiental. A questão da drenagem urbana no Brasil: elementos para formulação de uma política nacional de drenagem urbana. [Brasília], 2003.

CARLOS, A. F. A. A (re)produção do espaço urbano. São Paulo: Edusp, 1994.

CASSETI, V. Ambiente e apropriação do relevo. São Paulo: Contexto, 1991.

CHAMMA, G. V. F. Ponta Grossa: o povo, a cidade e o poder. Ponta Grossa: PMPG, SMEC, 1988. 
CHAVES, N. B. et al. Visões de Ponta Grossa. Ponta Grossa: UEPG, 2001.

CORRÊA, R. L. A periferia urbana. Geosul, Florianópolis, n. 2, v. 2, p. 70-78, 1986.

ESRI - ENVIRONMENTAL SYSTEMS RESEARCH INSTITUTE. Using ArcGIS 3D Analyst. Redlands: ESRI, 2008.

GRAZIA, G. de; LEÃO JÚNIOR, P. S. M. Loteamentos clandestinos e irregulares. In: INSTITUTO PÓLIS. Regularização da terra e da moradia: o que é e como implementar. São Paulo, 2002. p. 61-69.

GROSTEIN, M. D. Metrópole e expansão urbana: a persistência de processos "insustentáveis". São Paulo em perspectiva, São Paulo, v. 15, n. 1, p. 13-19, jan./mar. 2001.

HARVEY, D. A justiça social e a cidade. São Paulo: Hucitec, 1980.

IPEA - INSTITUTO DE PESQUISA ECONÔMICA APLICADA et al. Redes urbanas regionais: Sul. Brasília: IPEA, 2000.

LEFEBVRE, H. A cidade do capital. 2. ed. Rio de Janeiro: DP\&A, 2001.

LÖWEN, C. L. Favelas: um aspecto da expansão urbana de Ponta Grossa - PR. Rio Claro: UNESP, 1990 (Dissertação de Mestrado).

LÖWEN SAHR, C. L. Estrutura interna e dinâmica social na cidade de Ponta Grossa. In: DITZEL, C. de H. M; LÖWEN SAHR, C. L. (Orgs.). Espaço e cultura: Ponta Grossa e os Campos Gerais. Ponta Grossa, EdUEPG, 2001. p. 13-36.

MARICATO, E. Metrópole, legislação e desigualdade. Estudos avançados, São Paulo, v. 17, n. 48, p. 151167, 2003.

MATIAS, L. F.; NASCIMENTO, E. Geoprocessamento aplicado ao mapeamento das áreas de ocupação irregular na cidade de Ponta Grossa (PR). Geografia, Rio Claro, v. 31, n. 2, p. 317-330, mai.-ago., 2006.

MONASTIRSKY, L. B. A mitificação da ferrovia em Ponta Grossa. In: DITZEL, C. de H. M; LÖWEN SAHR, C. L. (Orgs.). Espaço e cultura: Ponta Grossa e os Campos Gerais. Ponta Grossa, EdUEPG, 2001. p. 37-51. MORO, D. Á. A modernização da agricultura paranaense. In: VILLALOBOS, J. U. G. (Org.). Geografia social e agricultura. Maringá: UEM, 2000.

NASCIMENTO, E.; MATIAS, L. F. Expansão urbana e desigualdade socioespacial: uma análise da cidade de Ponta Grossa (PR). Ra'ega: o espaço geográfico em análise, Curitiba, n. 23, p. 65-97, 2011.

NUNES, J. O. R.; SANT'ANNA NETO, J. L. A produção do espaço urbano e o destino dos resíduos sólidos. Caderno Prudentino de Geografia, p. 60-73, 2002.

PAULA, J. C. M. de. População, poder local e qualidade de vida no contexto urbano de Ponta Grossa PR. 1993, 192 f. Dissertação (Mestrado em Geografia) - Universidade Estadual Paulista "Júlio de Mesquita Filho" - Campus Rio Claro, Rio Claro, 1993.

RIBEIRO, L. C. de Q. Dos cortiços aos condomínios fechados: as formas de produção da moradia na cidade do Rio de Janeiro. Rio de Janeiro: Civilização Brasileira: 1997.

SANTOS, M. A urbanização brasileira. São Paulo: Hucitec, 1993.

SANTOS, M. A natureza do espaço. São Paulo: Hucitec, 1996.

SCHEFFER, S. M. Espaço urbano e política habitacional: uma análise sobre o programa de lotes urbanizados da PROLAR - Ponta Grossa, PR. Ponta Grossa: UEPG, 2003 (Dissertação de Mestrado).

SCHWARZ, R. Cultura e política. 2 ed. São Paulo: Terra e Paz, 2005.

SOUZA, M. L. de. ABC do desenvolvimento urbano. Rio de Janeiro: Bertrand Brasil, 2003.

SPOSATI, A. Cidade em pedaços. São Paulo: Brasiliense, 2001.

SPOSATI, A. et al. A pesquisa sobre segregação: conceitos, métodos e medições. Espaço e debates, São Paulo, v. 24, n. 45, p. 89-109, jan./jul. 2004 (debate).

VILLAÇA, F. Espaço intra-urbano no Brasil. São Paulo: Studio Nobel, FAPESP, Lincoln Institute, 1998. ZEILER, M. Modeling our World: the ESRI ${ }^{\circledR}$ guide to geodatabase design. Redlands: ESRI, 1999. 